\title{
DEVELOPMENT OF TOURISM IN THE CRIMEA AS AN ECONOMIC PROBLEM OF THE REGION
}

\author{
(C) Yulia A. Petrova, Anastasia A. Lebesheva, Artem V. Kamalov \\ Rostov State University of Economics, Rostov-on-Don, Russian Federation \\ science-almanac@mail.ru
}

Due to the inclusion of the Republic of Crimea into the structure of the Russian Federation the importance of studying of the tourist sector's state and development in a new territorial subject of Russia does not raise doubts. Modern global trends speak about the global scale of tourism development. Today tourism is one of the most important factors of the development of mutual understanding between ethnic groups and peoples and it makes the significant contribution to the prosperity of many countries of the world. In this regard, the assessment and characterization of the problems of development of tourist activity in the Republic of Crimea takes the powerful and independent place in the course of development and realization of strategy of national economy management. The history of recreational development of the Crimea and the documents, which were accepted and revised, are mentioned in our article. The purposes and the main directions of tourism development in the region are also stated in this article. One of the main tasks in the development of tourism in the region nowadays is the attraction of investments for the development of the infrastructure base of tourism and the ensuring of the quality of tourist service at the level of the world standards. In addition, there is a problem of a high level of shadow economy because of the non-payment of taxes by the citizens having a private ownership for use by tourists. Moreover, it should be noted that the economy of the Crimea is influenced by the seasonality of tourism, which slows down the peninsula development in cold season because of the low tourist flow. Of course, the development and realization of comfortable conditions for investors is needed for the investment attraction. Thus, investigating this article the readers learn about a number of problems of the tourism development in the Crimea and methods of their solving.

Key words: tourism, Crimea, economic problem.

\section{[Ю.А. Петрова, А.А. Лебешева, А.В. Камалов Развитие туризма в Крыму как экономическая проблема региона]}

В связи с включением Республики Крым в состав Российской Федерации актуальность изучения состояния и развития туристического сектора в новом субъекте России не вызывает сомнений. Современные глобальные тенденции говорят о глобальном масштабе развития туризма. Туризм сегодня является одним из важнейших факторов развития взаимопонимания между этническими группами и народами, а также вносит значительный вклад в процветание многих стран мира. В этой связи оценка и характеристика проблем развития туристической деятельности в Республике Крым занимает весомое и независимое место в процессе разработки и реализации стратегии управления экономикой страны. Мы также затронули историю рекреационного развития Крыма и документы, которые были приняты и пересмотрены, а также изложены цели и основные направления развития туризма в регионе. Одной из основных задач развития туризма в регионе в настоящее время является привлечение инвестиций для развития инфраструктурной базы туризма и обеспечение качества обслуживания туристов на уровне мировых стандартов.

Ключевые слова: туризм, Крым, туризм в регионе.

Yulia A. Petrova - candidate of philosophical sciences, associate professor of foreign languages for economic specialties. Rostov state university of economics. Rostov-on-Don, Russian Federation.

Петрова Юлия Андреевна - кандидат философрских наук, доцент кафедры иностранных языков для экономических специальностей. Ростовский государственный экономический университет. 2. Ростов-на-Дону, Российская Федерация. 
Anastasia A. Lebesheva - student. Rostov state university of economics. Rostov-on-Don, Russian Federation.

Лебешева Анастасия Алексеевна - студентка. Ростовский государственный экономический университет. е. Ростов-на-Дону, Российская Федерация.

Artem V. Kamalov - master Student, Rostov state university of economics, Rostov-on-Don, Russian Federation.

Камалов Артём Витальевич - студент магистратуры. Ростовский государственный экономический университет. е. Ростов-на-Дону, Российская Федерация.

The Crimea has always been the most popular holiday destination among Russians at the Black and Azov seaside. Fans of beach and active recreation, campsite fans, connoisseurs of natural beauty come here. Thanks to the geographical features of the peninsula, everyone can find a rest for themselves.

The history of the recreational development of the Crimea dates back to the second half of the XVIII century. With the improvement of transport links, it has become easier for residents of the Central provinces of the Russian Empire to reach the coast of the healing sea for rest and treatment.The Crimean coast has become a very popular and priority summer destination for the Russian nobility after visiting Catherine II.

From the end of the 19th till the beginning of the 20th centuries the Crimea began to be associated with many sonorous names among the Russian intellectuals, who acquired country houses in the Crimea. In summer you could meet a lot offamous writers, painters and artists of metropolitan theaters. Many of the estates are preserved in the Crimea to this day, which give a shade of mysterious antiquity to the appearance of the Crimean cities.

By the beginning of the 1870s, the road to the Crimea was facilitated by the construction of the Lozovo-Sevastopol railway. In 1875, the peninsula was connected with the center of the empire by the railway.

The new, mass stage in the history of Crimean tourism, in Soviet times, was associated with Lenin's decrees, and by the 1950s, the Crimea had become an "all-union health resort", receiving hundreds of thousands of tourists. Then, several tourist destinations developed on the peninsula at once: hiking, car and cycle tourism, children's leisure and climatic treatment.

Throughout the Soviet period, there was a steady increase in the capacity of the network of treatment and recreation facilities and a number of people who treated and rested in the Crimea. In 1988 the Crimea was visited by a record number of tourists (8.3 million people).

The war stopped the development of resorts of the Crimea. After the Victory, the stage of resorts restoring had come. Reconstruction of roads and stations was carried out, new health resorts were built.

In the 60-70 years the tourist explosion came in the Crimea. The collapse of the USSR hit the tourist industry of the peninsula. After 1991 the resort specialization changed dramatically: beach and active rest was preferred to sanatorium therapy. In general, there was a decline in the organized sanatorium and resort, as well as mountain tourism, with an increase in the share of the beach in its spontaneous form. Unorganized tourists ("savages") were significantly superior in the number of tourists in sanatoria; the private sector came out on top, placing up to $80 \%$ of holidaymakers in some years.

Starting its recovery in the early 2000 s, tourism on the peninsula was revived in a slightly different capacity, influenced by the economic and political realities of independent Ukraine, which controlled the Crimea before its actual inclusion into the structure of the Russian Federationin 2014. 
In connection with recent events (the return of the Republic of Crimea to Russia, sanctions and the devaluation of ruble), many Russians began to think more often about holidays in the Crimea. The magnificence of nature, ancient cultural monuments and the radiant sea are the richest recreational resource of domestic tourism.

After the Republic of Crimea had joined the Russian Federation, the whole set of documents was accepted and revised, they set out the goals and key directions for the development of tourism in the region. It is worth highlighting some of these documents:

- Strategy of tourism development in the Russian Federation for the period up to 2020;

- Strategy of social and economic development of the Republic of Crimea until 2030;

- State program for the development of resorts and tourism in the Republic of Crimea for 2017-2020.

The main goal in all the above documents is the formation of a modern tourist and recreational complex, which will be characterized by demand, competitiveness and diversity of the proposed health and tourist services as well as high quality service.

At the end of 2016, 5.5 million tourists visited the Republic of Crimea. It is $7.2 \%$ lower than the number of tourists in 2013, when the peninsula was a part of Ukraine, and it's $31 \%$ higher than the number of tourists in 2014 . However, despite the positive trend of a gradual increase in the number of tourists in the Crimea, the situation with the organization of the tourist complex on the peninsula remains far from desirable.

According to the Minister of Resorts and Tourism of the Crimea, E. Yurchenko, at the moment there are 825 campers accommodating holidaymakers on the peninsula, but only about 20 hotels are "no worse than Turkish or Egyptian", where the "all-inclusive" system operates. She also noted that the restoration of each object would require about \$ 5-6 million.

Today, in the framework of the Strategy for Socio-Economic Development of the Republic of Crimea until 2030, funding is being provided to create six tourist and recreational clusters on the territory of the peninsula that will combine the uniqueness of the Crimean region and the world standards, which will enhance the quality and competitiveness of the tourist product on the peninsula.

The next problem is a high level of shadowing of the tourist economy. In recent years, about $50 \%$ of the total tourist flow is accepted by the private households that are not taxable and to which state statistical reporting does not apply. To solve this problem, it is necessary to develop systems for identifying "shadow" subjects and further control systems over their activities, as well as increasing the number of registered accommodation facilities. As a result, the inflow of tax revenues to the budget of both the region and the country will increase, and thus additional resources will appear for the development of the Crimean peninsula.

In addition, it is worth noting the problem of the seasonality of the tourist sector in the Crimea. This is reflected in the intensity of loading of accommodation facilities and entertainment, on the number of jobs. In this regard, it is possible to single out at least seven months, characterized by low sales figures, which affect both the purchasing power of citizens and the development of the region.

The existing institutional mechanisms are aimed at the stable running enterprises, while the actual task is to support the possibility of starting new enterprises. Existing deficiencies affect the regional investment policy. Investment attractiveness declines due to the investors' non-confidence in the proper obligations enforcement. The first priority here is the creation of new institutional and cooperation mechanisms maximum favorable for investors and allowing to reverse the current negative tendencies. 
In this regard, one of the main tasks in the development of tourism in the region is the attraction of investments for the development of the infrastructure base of tourism and the ensuring of the quality of tourist service at the level of the world standards. Rostourism, for its part, pays great attention to expanding cooperation with banking and credit organizations. In particular, within the framework of the recently signed agreement RNKB Bank will participate in financing investment programs and projects focused on the development of tourism in the Crimean Federal District.

In conclusion, we need to state our final efficient actions helping tourism in the Crimean region. It is necessary to develop a unified concept for the creation and implementation of green routes, including a specific set of measures:

- Development of a network of green routes on the territory of objects of the natural reserve fund with the presence of the main and accompanying infrastructure that meets the principles of "green economy".

- Assistance to the development of cooperation between the subjects of tourist business and specialized public organizations in the organization of ecological tours and expeditions.

- The introduction of a monitoring system to ensure the quality and environmental friendliness of tourist-recreational and hotel services.

- Creation of a network of tourist information centers on the territory of objects of the natural reserve fund to perform the functions of environmental education.

- It should be noted that the problems of tourism development in the Crimea are not unique and difficult to overcome. There is a wide international experience that needs to be studied and implemented, adapting it to the local realities.

\section{Лumepamypa}

1. Федеральное агентство по туризму. Министерство экономического развития Российской Федерации. 2016.

2. Ромашина Н.A. Проблемы развития туризма в республике Крым // Электронный научный журнал «Международный студенческий научный вестник». 2017. №6 // Режим URL: http://www.eduherald.ru/

3. Сталиновская А.Туризм в Крыму: есть ли перспективы развития // Общественно-политический онлайн журнал «ПолитЭксперт», 2016. Режим URL: https://politexpert.net/

4. Кучмаева О.В., Махова О.А. Развитие туристической сореры в республике Крым: проблемы и оценка. 2015 // Научная электронная библиотека «КиберЛенинка». Режим URL: https://cyberleninka.ru/

5. Гнилицкая Т.И., Щербакова Д.А., Абрамова Л.С. Перспективы развития туризма в Крыму. 2017. // Режим URL: http://www.radnews.ru/

6. Объединенная авиастроительная корпорация. История развития туризма в Крыму. // Режим URL: http://оак-здоровье.pф/ (Дата обращения: 09.09.2018 г.)

7. Цуциева O.T., Джиоев А.В. Роль экономики знаний в устойчивом развитии регионов // Научный альманах Причерноморья. 2016. №2 // Режим URL: http://science-almanac.ru/

\section{References}

1. Federal Agency for Tourism. Ministry of Economic Development of the Russian Federation. 2016. 
2. Romashina N. A. Problems of the development of tourism in the Republic of Crimea. Electronic scientific journal "International Student Scientific Herald". 2017. №6 Available at: http://www.eduherald.ru/

3. Stalinovskaya A. Tourism in Crimea: are there any prospects for development. Social and political online magazine "PolitExpert", 2016. Available at: https://politexpert.net/

4. Kuchmaeva O.V. Makhova O.A. The development of the tourism sector in the Republic of Crimea: problems and assessment. 2015. CyberLeninka Scientific Electronic Library. Available at: https://cyberleninka.ru/

5. Gnilitskaya T. I., Scherbakova D.A., Abramova L.S. Prospects for the development of tourism in the Crimea. 2017. Available at: http://www.radnews.ru/

6. United Aircraft Corporation. History of tourism in the Crimea. Available at: http://оакздоровье.рф/

7. Tsutsieva O. T., Dzhioev A.V. The role of knowledge economy in sustainable development of regions. Science almanac of the Black Sea region countries. 2016. No 2. Available at: http://science-almanac.ru/

12 November, 2018 